\title{
Hunting dogs are at biggest risk to get attacked by wolves near wolves' territory boundaries
}

\author{
Mari Tikkunen ${ }^{1} \cdot$ Ilpo Kojola ${ }^{2}$ \\ Received: 1 November 2018 / Accepted: 4 July 2019 / Published online: 16 July 2019 \\ (C) The Author(s) 2019
}

\begin{abstract}
Wolves' attacks on hunting dogs are a major conflict between wolves and hunters in Northern Europe. The reasons affecting the risk of wolves' (Canis lupus) attacks on hunting dogs are poorly known. We examined whether the number of wolves in territory, the territory size, and the space use of GPS-collared wolves affected the risk of fatal attacks during hunting season in Finland. We found that attacks were more frequent within the periphery than core of the territory. Based on locations of GPS-collared wolves, wolves spent $8 \%$ (range $2-12 \%, n=17$ ) of time within the border zone (11\% of the territory area) of their territory. Forty-five percent of all attacks considered $(n=11)$ took place within this zone which was high proportion as compared to the distribution of wolf locations. This result might reflect wolves' motivational status to eliminate potential competitors when they are moving near territory boundaries.
\end{abstract}

Keywords Canid guild $\cdot$ Canis lupus $\cdot$ Dogs $\cdot$ Attacks $\cdot$ Risk $\cdot$ Space use $\cdot$ Territory

\section{Introduction}

Closely related canid species are likely to have partially overlapping ecological niches which is prone to cause interspecific aggression although also interspecific breeding is a well-known phenomenon within the canid guild (Ballard et al. 2003; Fritts and Paul 1989; Palomares and Caro 1999; Kojola et al. 2004; Sidorovich et al. 2003; Treves et al. 2002; Wabakken et al. 2001; Wydeven et al. 2003). Wolf (Canis lupus) attacks on hunting dogs (Canis familiaris) are a major conflict between wolves and hunters in Northern Europe (Kojola and Kuittinen 2002; Kojola et al. 2004; Backeryd 2007). Although the depredations on dogs are well known in many countries in Europe and

Communicated by: Krzysztof Schmidt

Mari Tikkunen

mari.tikkunen@gmail.com

Ilpo Kojola

ilpo.kojola@luke.fi

University of Oulu, PL 8000, FI-90014 Oulu, Finland

2 Natural Resources Institute Finland (Luke), Eteläranta 55, FI-96300 Rovaniemi, Finland
North America, they are not well documented in the scientific literature (Butler et al. 2015).

Unleashed dogs that run into wolves' territory seem to be considered as intruders or as competitors by wolves (Wydeven et al. 2003). In many cases, dogs are also consumed by the wolves, which indicate that they are also exploited as prey by the wolves (Backeryd 2007). However, dogs can be viewed as a minor dietary component of wolves (Lescureux and Linnell 2014).

Published scientific studies consider potential effects of wild prey (Kojola and Kuittinen 2002; Treves et al. 2002; Sidorovich et al. 2003; Kojola et al. 2004), dog (Kojola et al. 2004), and human residence densities (Murdock 1969) on the risk of the attacks by wolves. Results are diverse, and general conclusions about factors that explain variation among territories are not clear. Because wolves are strongly opportunistic animals and the elements of wolf-human conflict vary both spatially and temporally, case studies about wolves' depredations on dogs are poorly understood and still relevant. We examined whether the frequency of attacks by wolves was influenced by the territory size, the number of wolves living in the territory, and the space use by wolves.

According to Mech (1994), Mech et al. (1998), and Hayes (1995), most wolves killed by other wolves occur at territory borders. Also, Smith et al. (2015) concluded that most nondenning season attacks occur at the territory periphery. We 
studied whether this pattern also applied to wolf attacks on domestic dogs used for hunting. We assumed that the number of hunting dogs moving in the core and the periphery of the wolf territory is the same in Finland where a dense and evenly distributed network of forest roads with public access is apt to unify hunting activities across wolf territories. We focused on the hunting season because a great majority of wolf attacks on dogs concern hunting-related activities in Fennoscandia (Kojola et al. 2004; Backeryd 2007).

With our study, we aimed to obtain information for better understanding the intra-guild interactions between wolves and domestic dogs being the source of conflicts of wolves with humans.

\section{Methods}

\section{Study area}

Our study was conducted in 28 Finnish wolf territories of which 25 were located in east-central Finland. The study territories were located in boreal zone. The predominant tree species are Scotch pine (Pinus sylvestris) and Norway spruce (Picea abies) mixed with birches (Betula pendula and B. pubescens) and some other deciduous trees admixtures of several other tree species and young mixed forests. Young stands and clear-cuts are common. In east-central Finland, permanent snow usually appears in November and melts in late April and early May. In three southern territories, snowcovered season is $1-2$ months shorter.

\section{Data}

We collected data on fatal wolf attacks on dogs during 2003 2009 from the Agency for rural affairs and records for 2010 2015 from the register launched by Finnish Ministry of Agriculture and Forestry in 2010. The latter included exact geographic coordinates of the attacks, the first mostly only the attack locations reported as village names.

Wolves were captured mostly by darting them from a helicopter (see Kojola et al. 2016). A few wolves were captured by looping them from a snowmobile (see Kojola et al. 2006). Detailed protocols in capture and immobilization procedure are given elsewhere (Kojola et al. 2006).

The wolves collared with transmitters containing global positioning system (GPS) for locating wolves and global system for mobile (GSM) for getting locations (Vectronic Aerospace, Berlin, Germany). Four of the collared wolves were young wolves, which probably have not bred, but have established territories. The rest of the wolves were territorial adults. The capture, handling and anesthetizing of the wolves were made by the guidelines issued by the Animal Care and
Use Committee at the University of Oulu and permits provided by national Animal Experiment Board.

Movements by collared wolves and the number of wolves living in the given territory were recorded by the Natural Resources Institute of Finland. We used the data from the season that covers all essential dog-assisted hunting seasons (from Aug 20 to Feb 28). Out of 214 all attacks in Finland during 2010-2015, 195 took place during hunting seasons.

The interval between two successive locations was $4 \mathrm{~h}$. We included only the attacks that took place during wolf's tracking period. Tracking period includes the time after wolf has been collared by Luke's field technicians and when the collar stops working or for other reason, the collar does not send locations any more. The tracking period is different for each wolf. Mean duration of the GPS-study was 130 days (range 23-194, $n=28$ ). The number of wolves living in study territories was defined through tracking by Luke's field technicians after first snowfalls (October-November). Of 28 study territories, 18 were hosted by a family pack, 4 by a territorymarking pair, and 6 by a single resident wolf. Mean size of the family packs was 6 (range 3-11) wolves.

We used data from only 1 satellite-collared wolf per pack for the following analyses. However, the movements of one collared wolf are representative of the movements of the whole pack, because in autumn and winter, when the pack is nomadic, wolf pack moves mostly as one unit (Mech and Boitani 2003, 31; Okarma et al. 1998). If there were more than one wolf in the territory which was collared, we randomly selected one of the territorial wolves. Furthermore, in the cases where one collared wolf was tracked during more than 1 year, the year with most comprehensive data was selected for such wolves.

\section{Analysis}

We divided our data into territories with attacks and territories without attacks using all 28 territories with GPS-collared wolves from 2003 to 2015 . We used logistic regression to test whether these two groups differed in territory size and in the number of wolves in the territory, first for all territories $(n=$ $28)$ then for territories occupied by family packs $(n=18)$. Also the number of tracking days, slightly correlated (Pearson $r=$ 0.403 ) with territory size, was tested for.

Autumn territory sizes were calculated with fixed Kernel method (Seaman and Powell 1996; Blundell et al. 2001) using ad hoc smoothing parameter (Berger and Gese 2007; Jacques et al. 2009). Home range isopleths (50, 90, and 100\%) were then created based on Kernel density and viewed in ArcMap 10.3., where we also viewed the coordinates from the wolf attacks on dogs and visually examined the attack locations on the territories.

To study if there were more fatal attacks within peripheral zones of wolf territories, we analyzed location of attacks in 
relation to the spatial distribution of the territory. These analyses include attacks between the years 2010 and 2015 from which time we have the exact coordinates of the attack places (Fig. 1).

The periphery was defined as the area between $100 \%$ and the $90 \%$ isopleths. To see how much of their time wolves spend in the periphery, we calculated the number of GPS fixes in periphery and counted their proportion from all fixes in the territory during the tracking period.

We examined distances of kill sites from territory boundaries to map potential risk zones based on Mech's (1994) finding that wolf intraspecific attacks are most frequent near territory boundaries. We used $100 \%$ Kernel isopleth for the assessment of territory boundary. The distance was the perpendicular distance to the closest edge of the territory. To scale against shape and size of different territories, we used the assumption of circular shaped territories and calculated the location of kill sites as percentages of the territory radius (cf. Mech 1994).

We compared the distribution of attacks in the border zone (the area between 100\% and 90\% Kernel home ranges) and elsewhere within the territory with the expected values based on the locations of GPS-collared wolves by using Fisher's exact test. We used SPSS package (version 24) in statistical analyses.

\section{Results}

There were wolf attacks on dogs in 12 of 28 territories during GPS tracking in 2003-2015. According to logistic regression, territories with and without attacks did not differ by the number of tracking days, the number of wolves in the territory and territory size (all $p$ values $>0.2$ ) for all territories, including pairs and the single wolves. Also territories with and without attacks, hosted by family packs, did not differ by these variables (all $p$ values $>0.15$ ).

Mean size of wolves' territories was $1307 \mathrm{~km}^{2}$ (range 580 $2330 \mathrm{~km}^{2}$; $\left.\mathrm{SE}=178\right)$. During the period 2010-2015 when the exact locations of attacks were available ( $n=17$ territories), the locations of GPS-collared wolves in the periphery of their territories (area between 90\% and 100\% Kernel isopleths) constituted on average $8 \%$ (range $2.0-12.0 \%$ ) of locations.

Wolf attacks on dogs were more common within the periphery than can be expected from wolves' locations (Fig. 2). Almost half of the attacks between 2010 and 2015 inside the territory $(45 \%, n=11)$ took place within the periphery which is more often than can be expected as compared to the distribution of wolf locations. The observed distribution differed nearly significantly from the expected distribution (Fisher's exact $p=0.063$ ).

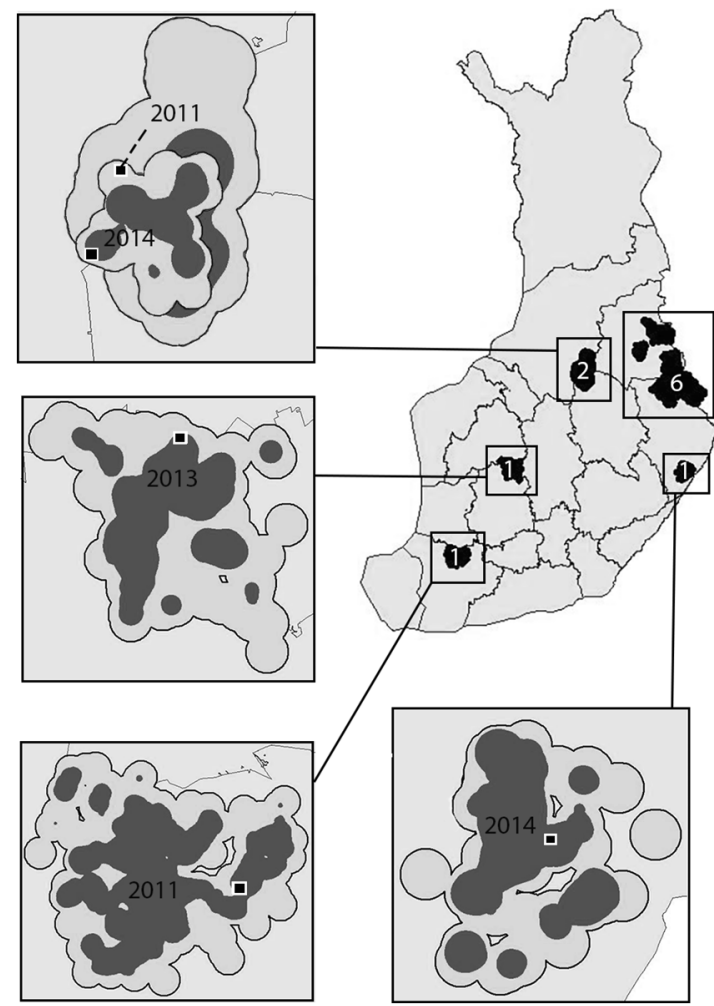

Fig. 1 Wolf territories in Finland, where attacks have taken place $(n=$ 11), during the period 2010-2015 for which detailed data on attacks on domestic dogs were available. The peripheral parts of territories are defined as the area between isopleths of Kernel 100\% (white) and $90 \%$

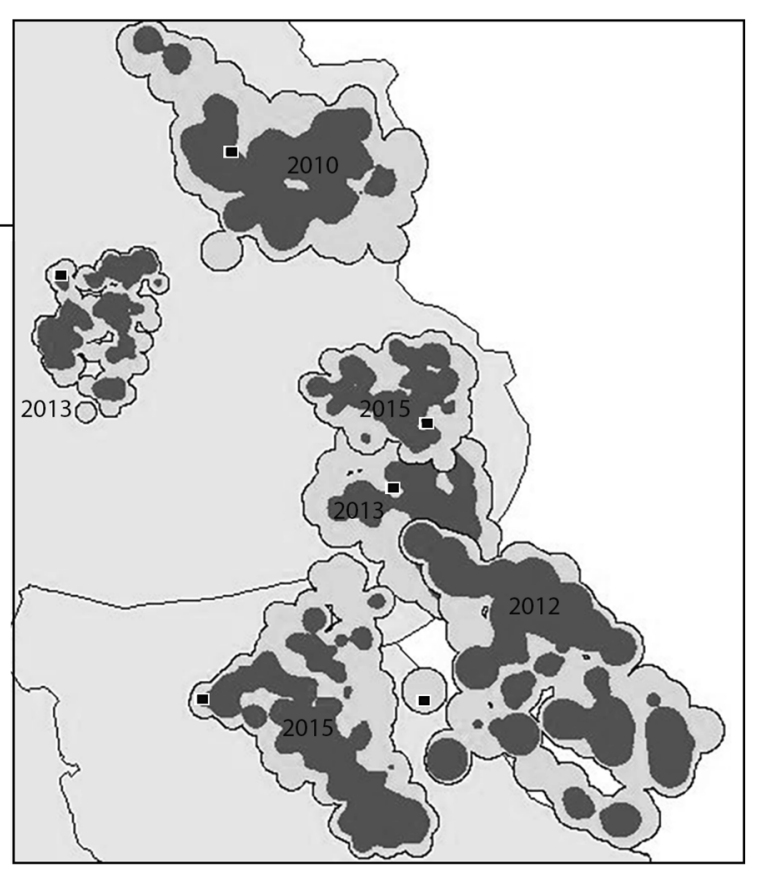

(gray) ranges. The locations of dogs killed in territories are indicated by dots. The numbers in the map indicate the number of territories in that area and the year indicates the year when wolves' attack on dog has taken place in that particular territory 

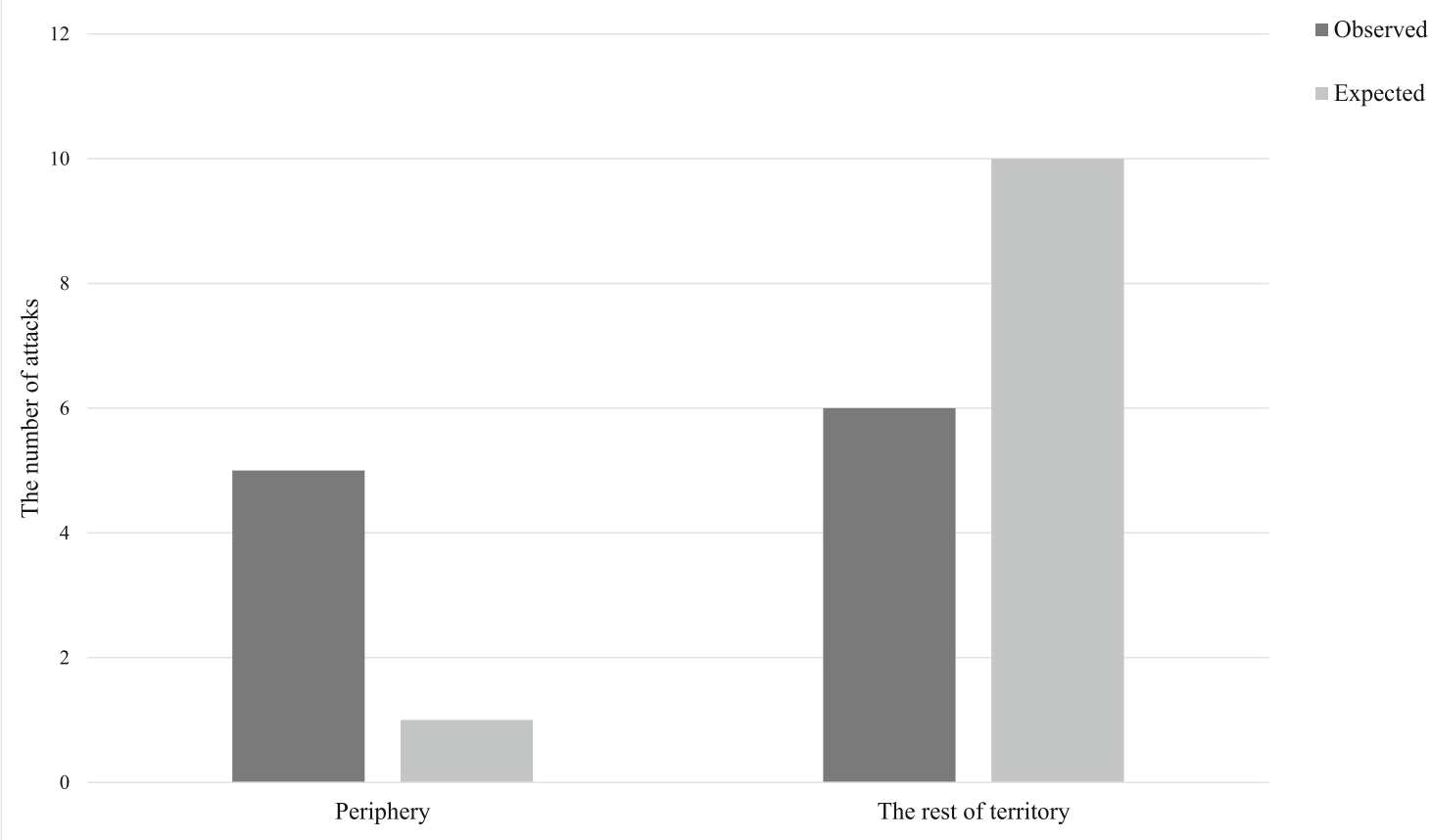

Fig. 2 The number of attacks in the periphery of the wolf's territory and elsewhere in the territory and the expected number of attacks based on the location of GPS-collared wolves

Attacks on dogs were concentrated near territory boundaries. Whereas the mean radius of territories was $19.9 \mathrm{~km}$ (range 13.6-27.2 km; SE $=1.4$ ), the mean distance of the attack from the territory boundary was $5.4 \mathrm{~km}$ (range $0.3-$ $12.6 \mathrm{~km} ; \mathrm{SE}=1.2, n=11$ ). The mean distance of the attack from the boundary of territory constituted $28.5 \%$ ( $\mathrm{SE}=5.3$ ) of the average radius of territories (Fig. 3).

\section{Discussion}

The number of tracking days, pack size, and territory size did not affect the risk of wolf attack on dogs within the wolf territories in our study. However, our results provided evidence that dogs can be at higher risk to get attacked by wolves within the periphery than the core of the wolf territory. By considering these findings as outcomes from intra-guild competition, we follow conclusions by Mech (1977b, 1994), Hayes (1995), and Mech et al. (1998), indicating that the risk of confrontations between neighboring packs is highest at territory boundaries.

There are, however, apparently significant differences between the wolf spatial behavior in Minnesota (studies by Mech 1977b, 1994) and Finland. In Finland, territory sizes are bigger and there are no as clear buffer zones (areas between wolf pack territories, which are situated around the edge of a wolf pack territory where neighboring packs travel but spend less time; Mech 1977b, Mech and Harper 2002) as in Minnesota between neighboring territories (I. Kojola et al. unpublished data), but as we can see from the results of this study, some kind of zones of confrontation do exist also in Finland. Inside the territory areas where most wolf-wolf or wolf-dog attacks took place $(50 \%$ of the mean radius of territories according to Mech 1994) are wider (10 km) in Finland than in Minnesota (3.2 km, cf. Mech 1994), probably because of larger territories in Finland. Despite these differences, the proportion of attacks, either wolf-wolf or wolf-dog, taking place within this $50 \%$ zone of confrontation was similar in Finland (82\% of wolves' attacks on dogs in this study) and in Minnesota (91\% of wolf-wolf attacks, cf. Mech 1994).

Intraspecific predation is common among animals and at least 14 species of carnivorous mammals sometimes attack and eat conspecifics (Polis 1981), but the reason for intraspecific killing is likely primarily competition rather than intraguild predation for food (Merkle et al. 2009). Wolves are particularly aggressive towards strange wolves that invade their territories, and intraspecific aggression is the most frequent cause of wolves' mortality (Cubaynes et al. 2014; Mech 1977a, 1994). Anyhow, the species may benefit not only from exclusion of the competitor but also from its consumption (Backeryd 2007). In the study of Kojola and Kuittinen (2002), all but one of the attacked dogs have been eaten, also the ones attacked in the forest. In Minnesota, $75 \%$ of the killed 
3,5

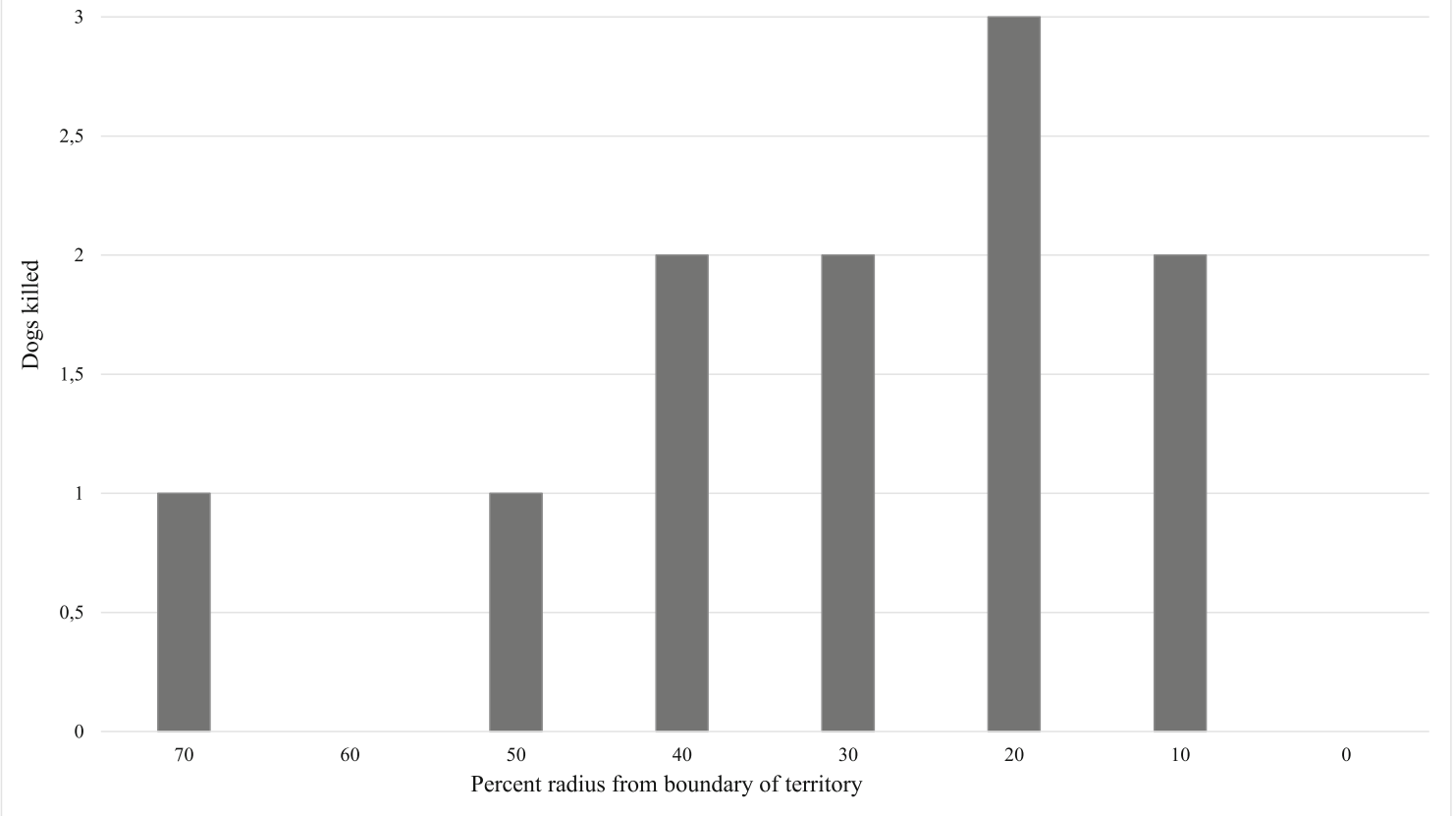

Fig. 3 Dog kill site location along the radius of the territory as percentage of the radius from the territory boundary

dogs were eaten (Fritts and Paul 1989). The role of competitors as a source of energy is however small (Palomares and Caro 1999). It is suggested (Karlsson and Thoresson 2001; Kojola and Kuittinen 2002; Wydeven et al. 2003) that dogs attacked in the house yards are preferred more as a prey by wolves than dogs attacked in the forest.

Although wolves do not spend much time in the peripheral zones of their territory, they still defend and mark them actively (Peters and Mech 1975). According to Zub et al. (2003), wolves' scent marks in territory are concentrated in "hot spots" more vulnerable to penetration by intruders (borders bounded other territories) or more valuable to owners (surroundings of dens). Borders of territories in canids seem to be distinct and well recognized by neighboring individuals. For example in coyotes (Canis latrans), resident territory owners do not preferably cross the borders even when chasing an intruder (Gese 2001) or when threatened by humans (Neale et al. 2007). When meeting an intruder, wolves typically kill it (Mech 1994) while coyotes rarely do so (Gese 2001).

Territorial behavior and defending territory borders are not typical only for the canids, but also for other carnivores from other families as felids. Female lions (Panthera leo) more likely approach intruders when in peripheral areas of the territory than when in core areas (Spong and Creel
2004). Lions are probably more prepared for encounters when close to the territory border, and thus more willing to engage in territorial disputes. A response to intruders as soon as they trespass may be more effective than responding in core areas (Spong and Creel 2004). These findings suggest a common pattern of territorial behavior in carnivores, which support the conclusions of our study that wolves are very aware of their territory borders and defend them very effectively by eliminating potential competitors as domestic dogs.

Territory boundaries are very difficult to identify without GPS-collared wolves. Therefore, hunters with hunting dogs can benefit from spatial distribution of the territory only where wolves are collared. In Finland, the last locations of GPScollared wolves are publicly available at $5 \times 5 \mathrm{~km}$ resolution, which can to some extent be used to guide hunters of areas of higher potential risk. According to unpublished attitude surveys (Finnish Wildlife Agency), hunters are pleased to such public information. This kind of service does not fix the problem at broader scale because only the minority of territories are occupied by collared territorial wolves. Because the risk of attacks on dogs is a major conflict between wolves and hunters and potentially an important motivation for illegal killing of wolves, technical innovations to protect dogs more efficiently should be developed. 
Acknowledgements Open access funding provided by University of Oulu including Oulu University Hospital.

Open Access This article is distributed under the terms of the Creative Commons Attribution 4.0 International License (http:// creativecommons.org/licenses/by/4.0/), which permits unrestricted use, distribution, and reproduction in any medium, provided you give appropriate credit to the original author(s) and the source, provide a link to the Creative Commons license, and indicate if changes were made.

\section{References}

Backeryd J (2007) Wolf attacks on dogs in Scandinavia 1995-2005. Will wolves in Scandinavia go extinct if dog owners are allowed to kill a wolf attacking a dog? Lantbruksuniversitet, Sverige, Examensarbete

Ballard WB, Carbyn LN, Smith DW (2003) Wolf interactions with nonprey. In: Mech LD, Boitani M (eds) Wolves: behavior, ecology and conservation. University of Chicago Press, pp 259-271

Berger KM, Gese EM (2007) Does interference competition with wolves limit the distribution and abundance of coyotes? J Anim Ecol 76(6): 1075-1085

Blundell GM, Maier JAK, Debevec EM (2001) Linear home ranges: effects of smoothing, sample size, and autocorrelation on kernel estimates. Ecol Monogr 71(3):469-489

Butler JRA, Linnell JDC, Morrant J, Athrey V, Lescureux N, McKeown A (2015) Dog eat dog, cat eat dog: social-ecological dimensions of dog predation by wild carnivores. In: Gompper ME (ed) Freeranging dogs and wildlife conservation. Oxford University press, pp 117-143

Cubaynes S, MacNulty DR, Stahler DR, Quimby KA, Smith DW, Coulson T (2014) Density-dependent intraspecific aggression regulates survival in northern Yellowstone wolves (Canis lupus). J Anim Ecol 83:1344-1356

Fritts SH, Paul WJ (1989) Interactions of wolves and dogs in Minnesota. Wildl Soc Bull 17(2):121-123

Gese EM (2001) Territorial defense by coyotes (Canis latrans) in Yellowstone National Park, Wyoming: who, how, where, when, and why. Can J Zool 79(6):980-987

Hayes RD (1995) Numerical and functional responses of wolves and regulation of moose in the Yukon. In: Mech LD, Boitani M (eds) Wolves: behavior, ecology and conservation. University of Chicago Press, $\mathrm{p} 25$

Jacques CN, Jenks JA, Klaver RW (2009) Seasonal movements and home-range use by female pronghorns in sagebrush-steppe communities of western South Dakota. J Mammal 90(2):433-441

Karlsson J, Thoresson S (2001) Jakthundar i vargrevir - En jämförelse av jakthundsanvändningen i fem olika vargrevir och statistiken över vargangrepp på hundar 1999/2000. Raport. Viltskadecenter, Grimsö, Sverige

Kojola I, Kuittinen J (2002) Wolf attacks on dogs in Finland. Wildl Soc Bull 30(2):498-501

Kojola I, Ronkainen S, Hakala A, Heikkinen S, Kokko S (2004) Interactions between wolves Canis lupus and $\operatorname{dogs} C$. familiaris in Finland. Wildl Biol 10(2):101-105

Kojola I, Aspi J, Hakala A, Heikkinen S, Ilmoni C, Ronkainen S (2006) Dispersal in an expanding wolf population in Finland. J Mammal 87(2):281-286

Kojola I, Hallikainen V, Mikkola K, Gurarie E, Heikkinen S, Kaartinen S, Nikula A, Nivala V (2016) Wolf visitations close to human residences in Finland: the role of age, residence density, and time of day. Biol Conserv 198:9-14
Lescureux N, Linnell JDC (2014) Warring brothers: the complex interactions between wolves (Canis lupus) and dogs (C. Familiaris) in a conservation context. Biol Conserv 171:232-245

Mech LD (1977a) Productivity, mortality and population trends of wolves in northeastern Minnesota. J Mammal 58(4):559-574

Mech LD (1977b) Wolf-pack buffer zones as prey reservoirs. Science 198(4314):320-321

Mech LD (1994) Buffer zones of territories of gray wolves as regions of intraspecific strife. J Mammal 75(1):199-202

Mech LD, Boitani M (eds) (2003) Wolves: behavior, ecology and conservation. University of Chicago Press

Mech LD, Harper EK (2002) Differential use of a wolf, Canis lupus, pack territory edge and core. Can Field Nat 116(2):315

Mech LD, Adams LG, Meier TJ, Burch JV, Dale BV (1998) The wolves of Denali. In: Mech LD, Boitani M (eds) Wolves: behavior, ecology and conservation. University of Chicago Press, p 25

Merkle JA, Stahler DR, Smith DW (2009) Interference competition between gray wolves and coyotes in Yellowstone National Park. Can J Zool 87(1):56-63

Murdock WW (1969) Switching in general predators: experiments on predator specificity and stability of prey populations. Ecol Monogr 39:335-354

Neale JCC, Sacks BN, Blejwas KM (2007) Coyote flight movements relative to territory boundaries: an experiment in the field. Am Midl Nat 158(1):162-167

Okarma H, Jedrzejewski W, Schmidt K, Sniezko S, Bunevich AN, Jedrzejewska B (1998) Home ranges of wolves in Bialowieza Primeval Forest, Poland, compared with other Eurasian populations. J Mammal 79(3):842-852

Palomares F, Caro TM (1999) Interspecific killing among mammalian carnivores. Am Nat 153(5):492-508

Peters R, Mech LD (1975) Scent-marking in wolves: a field study. Am Sci 63:628-637

Polis GA (1981) The evolution and dynamics of intraspecific predation. Annu Rev Ecol Evol Syst 12:225-251

Seaman DE, Powell RA (1996) An evaluation of the accuracy of Kernel density estimators for home range analysis. Ecology 77(7):2075-2085

Sidorovich VE, Tikhomirova LL, Jedrzejewska B (2003) Wolf Canis lupus numbers, diet and damage to livestock in relation to hunting and ungulate abundance in northeastern Belarus during 1990-2000. Wildl Biol 9(2):103-111

Smith DW, Metz MC, Cassidy KA, Stahler EE, McIntyre RT, Almberg ES, Stahler DR (2015) Infanticide in wolves: seasonality of mortalities and attacks at dens support evolution of territoriality. J Mammal 96(6):1174-1183

Spong G, Creel S (2004) Effects of kinship on territorial conflicts among group of lions, Panthera leo. Behav Ecol Sociobiol 55(4):325-331

Treves A, Jurewicz RR, Naughton-Treves L, Rose RA, Willging RC, Wydeven AP (2002) Wolf depredation on domestic animals in Wisconsin, 1976-2000. Wildl Soc Bull 30(1):231-241

Wabakken P, Sand H, Liberg O, Bjärvall A (2001) The recovery, distribution, and population dynamics of wolves on the Scandinavian peninsula, 1978-1998. Can J Zool 79(4):710-725

Wydeven AP, Treves A, Brost B, Wiedenhoeft JE (2003) Characteristics of wolf packs depredating on domestic animals in Wisconsin, USA. In: Fasciore N, Delach A, Smith M (eds) Predators and people: from conflict to conservation. Island Press, Washington, pp 1-36

Zub K, Theuerkauf J, Jedrzejewski W, Jedrzejewska B, Schmidt K, Kowalcyk R (2003) Wolf pack territory marking in the Bialowieza primeval forest. Behaviour 140(5):635-648

Publisher's note Springer Nature remains neutral with regard to jurisdictional claims in published maps and institutional affiliations. 